
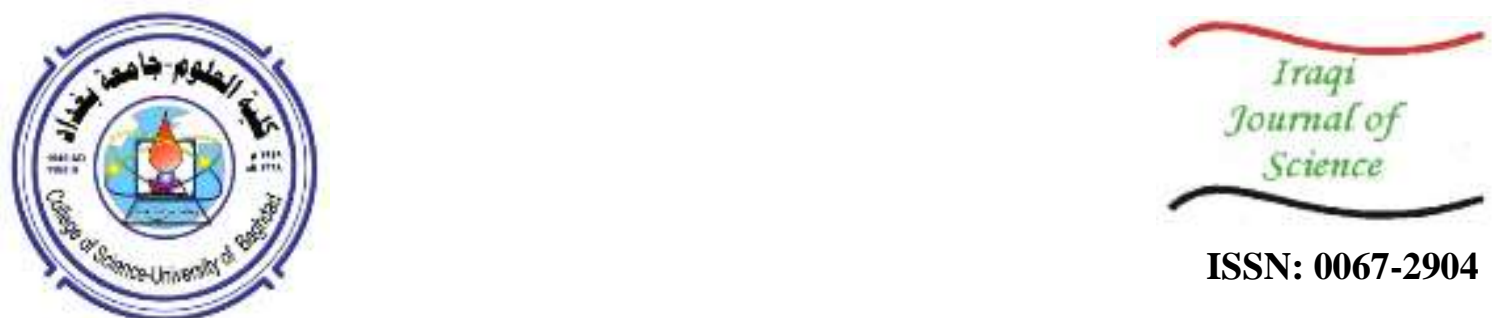

ISSN: 0067-2904

\title{
Histological Changes in Kidney and Spleen of Albino Mice Treated with Brake Pad Particles
}

\author{
Nada Abdulrahman F. Al-Easawi ${ }^{1}$, Hajer Qais Ghaidan ${ }^{1}$, Shahad Mansour Salman*2 \\ ${ }^{1}$ Department of Biology, College of Science, University of Baghdad, Baghdad, Iraq \\ ${ }^{2}$ College of Pathological Analysis Techniques, Al-Bayan University Baghdad, Iraq
}

Received: $22 / 5 / 2019$

Accepted: $17 / 7 / 2019$

\begin{abstract}
In this study, the consequences of treatment with brake pad particles on kidney and spleen were evaluatedthrough microscopic anatomy sections for 60 male albino mice. The animals were divided into six groups, the first three groups $(\mathrm{A}, \mathrm{B}, \mathrm{C})$ were exposed to brake pad particles depending on periods of exposure $(4,8$, and 12 weeks, respectively), while the other three groups were control groups,designated asF, which were exposed to laboratory fresh air only. A special locally-designed inhalation chamber was used to expose the animals. The exposure dose to brake pad particles (total suspended particles) was $2.228 \mu \mathrm{g} / \mathrm{m}^{3}$ for $30 \mathrm{~min} /$ day, 5 days/week,4, 8 and 12 weeks.The statistical analysis showed that the weights of organs for both kidney and spleen of treated mice had highly significant differences $(\mathrm{P}<0.01)$ compared with control groups.The histological sections examination of the kidney, when compared with the control group, showed subcapsular tubular vascular degeneration and mild cortical focal hemorrhage in group A that was exposedto brake pads particlesfor 4 weeks. In group B, the exposure for 8 weeks resulted in cortical vascular degeneration, cortico-medullary vascular congestion, focal interstitial nephritis, and thickening of interstitial tissue.Other effects included marked dilation of collecting ducts with tubular vascular degeneration, necrosis, glomerular degeneration and deterioration, and cast formation. Group C, exposed for 12 weeks , showed similar changes of the kidney to those of group B. As related to spleen sections,they demonstrated mild subcapsular vascular degeneration of lymphocytes in group A,while the exposure in group Bresulted in moderate amyloid deposits with hemosiderosis, along withmild subcapsular vascular degeneration of lymphocyteswithin the red pulp. In group C, which was treated for 12 months, severe splenomegaly with advanced secondary splenic amyloidosis was also observed within the red pulp.It was characterized by marked deposited acellular and amorphous pinkish homogenous material within red pulp.The continuous exposure to brake pad particles causes harmful effectson the tissues ofessential body organs in human health.These particles should be thought-about as a sort of additional air pollutants in several cities of Iraqin the future.
\end{abstract}

Keywords: Kidney, Spleen, Car brake pad particles, Metallic elements.

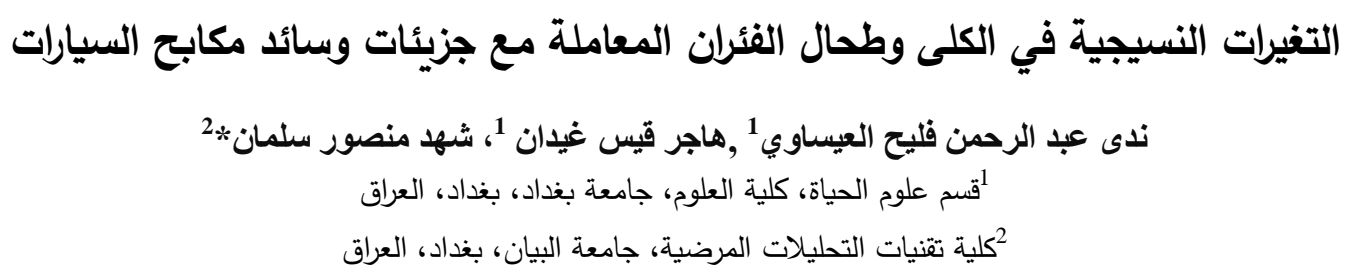

*Email: shahad.man2020@gmail.com. 


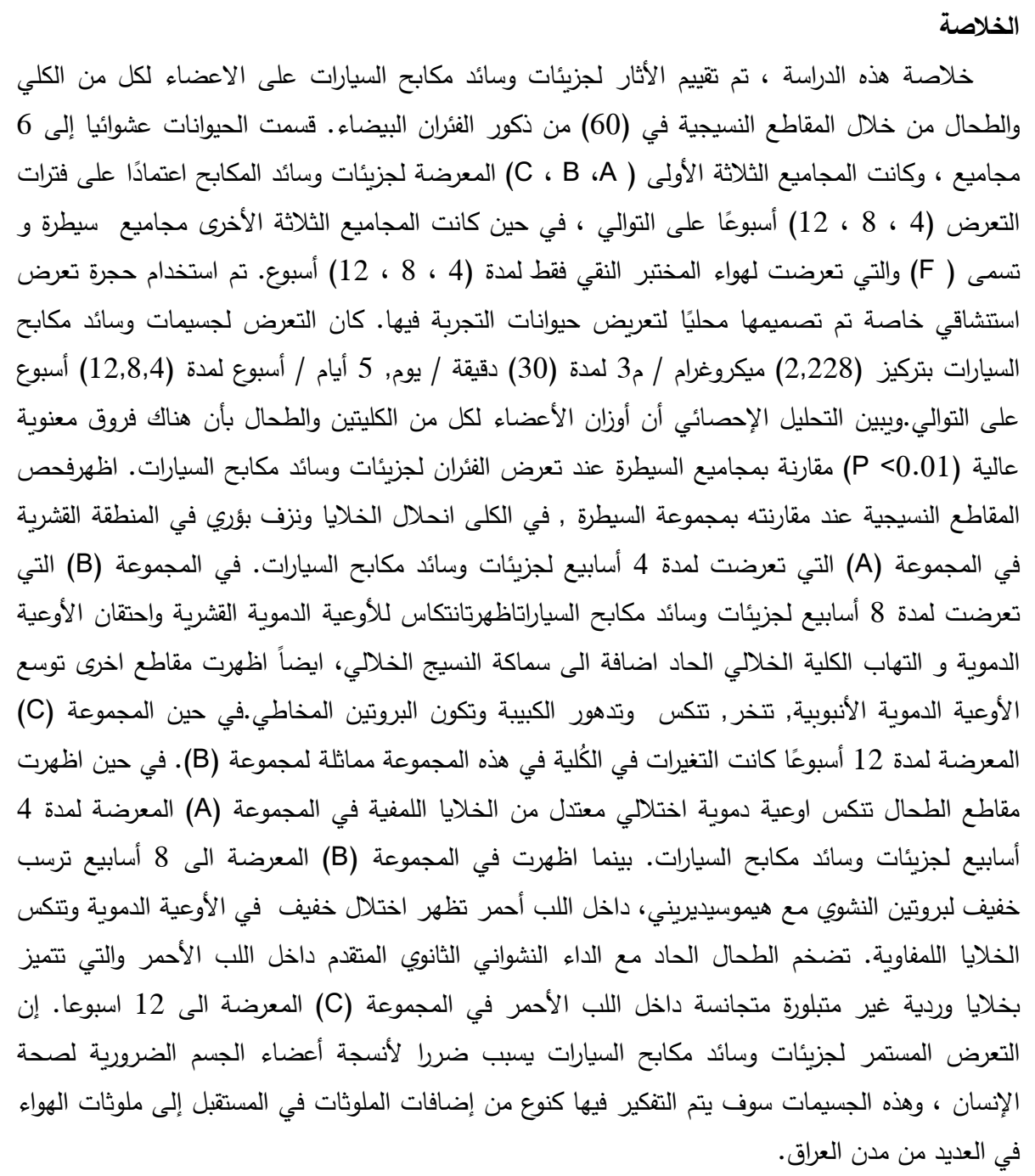

\section{2- Introduction}

Air is the most essential element needed for survival, and without it, humans can die in a course of 5 minutes [1,2]. Humans breathe nearly 22000 times and inhale around $15 \mathrm{Kg}$ of air per day [3]. The increasing number of vehicles in the roads causes a direct impact of air pollution, resulting from an exhaust and non-exhaust pollutants (brake, clutch, tire wear, road surface wear and corrosion of vehicle components) [4].

The brake system on the most modernistic passenger vehicles is not sealed with a cover from the ambient air.The brake pad particles are generated from the contact between the pads and the rotor (gray cast iron) in the brake system of vehicles. Studies in Europe observed that the airborne particulate matter (PM) produced from friction between the rotor and the pad of the brake contributes to up to $50 \%$ of the total road emissions [5].

Most rotors are made of grey cast iron, whilethe brake pads can be made of complex different materials.There are five types of brake pads, divided according to the amount of metallic elements and the temperaturecapacity; first) non-asbestos organic (NAO) pads, second) metallic pads, third) semimetallic pads, fourth) low metallic (LM) pads, fifth) ceramic brake pads. In addition, brake pad linings typically comprise five main components; 1) binders $(20 \%-40 \%), 2)$ reinforcing fibers $(6 \%-35 \%)$, $3)$ fillers $(15 \%-70 \%)$, 4) frictional additives or lubricants $(5-29 \%), 5)$ abrasives $(\sim 10 \%)[6,7,8]$. Non-exhaust emission is an urban air pollutant where the particles can be found on paved roads and can considerably enhance atmospheric particulate matter levels [9, 10]. The atmosphere carries airborne particulate matter of various sizes, usually divided according to their diameters into $\mathrm{PM}_{10}$ (less than $10 \mu \mathrm{m})$ and $\mathrm{PM}_{2.5}($ less than $2.5 \mu \mathrm{m})[11]$.

The most important non-exhaust traffic-related sources were considered to be the brake wear emissions. Several studies in urban environments observed that non-exhaust traffic-related sources 
contributed to up to $55 \%$ of mass of total suspended particles (TSP) [12]. Total traffic-related (brake wear) particles with less than $10 \mu \mathrm{m}$ diametercomprise around $21 \%$ of the particulate matter mass [13]. The fine particles $\mathrm{PM}_{2.5}$ were reported to cause adverse results on human health [14]. Based on epidemiological studies, it was reported that a level of $10 \mu \mathrm{g} / \mathrm{m}^{3}$ of fine particles would be associated with a $1.4 \%$ increase in mortality, so that, there is a significant relationship between human mortality and concentration of fine particles $\mathrm{PM}_{2.5}$ [15]. These particles could be transported by blood into other organs such as lung, liver, kidney, brain, and other organs [16]. The fact that these particles can be inhaled alsohasa great influence on their toxicity level.They contain high levels of some heavy metals $(\mathrm{Fe}, \mathrm{Zn}, \mathrm{Cu}, \mathrm{Mn}, \mathrm{Pb})$ and other elements, so that, these particles lead to oxidative stress and an increase of pro-inflammatory responses $[17,18]$.

The goal of the present work is to evaluate the effects of brake pad particles on organ weightand histology of murine kidney and spleen,to determine whether or not pad particles can alter the functions of these organs.

\section{3- Materials and Methods}

A total of 60 healthy mature albino male mice at an age range of 7-9 weeks and weight range of 19$29 \mathrm{~g}$ were included in the present study. The tested animals were divided into 6 groups depending on the inhalation exposure periods (Table 1-1).

Table 1.1-Groups of animals in experimental design F: Fresh air; A: Group exposed for 4 weeks; B: Group exposed for 8 weeks and C: Group exposed for 12 weeks.

\begin{tabular}{|c|c|c|c|}
\hline $\begin{array}{c}\text { Group } \\
\text { No. }\end{array}$ & Exposure period (weeks) & $\begin{array}{c}\text { Number of control } \\
(\mathbf{F})\end{array}$ & $\begin{array}{c}\text { Number of animals } \\
\text { exposed }\end{array}$ \\
\hline A & 4 & 10 & 10 \\
\hline B & 8 & 10 & 10 \\
\hline C & 12 & 10 & 10 \\
\hline
\end{tabular}

The whole-body exposure chamber was locally made from glass.This chamber is classified as a dynamic system and principally used for chronic exposure studies in an oversized range of laboratory animals $[19,20]$.

Three groups of animals $(\mathrm{A}, \mathrm{B}, \mathrm{C})$ were exposed to brake pad particles in line with the following regime: Group A were exposed for 4 weeks, group B were exposed for 8 weeks and group C were exposed for 12 weeks, under a concentration of $2.228 \mu \mathrm{g} / \mathrm{m}^{3}$. Pad particles were created inside a Dust Generation Box (DGB) for 5 min daily, then each animal group was exposed to brake pad particles for $30 \mathrm{~min} /$ day, 5 days/week, 4, 8 and 12 weeks, respectively.

The device consists of three basic parts; the primary part is an electric motor connected with a long shaft and a rotary sharpening disc that operates inside a Dust Generation Box (DGB). The other end inside the DGB is associated with a vacuum fan used for vacuuming the dust (pad particles), through an iron-made duct,into the glass inhalation chamber that contains the mice under treatment. Animals within the inhalation chamber were cluster-placed in tiny cages exposed for 30 minutes/day, while the control group was exposed to fresh air only. This procedure was followed throughout every exposure amount.The inhalation chamber contains a fan that works throughout the exposure period,in addition to a blower that is used to continuously spread pad particles inside the exposure chamber. Alcohol was used with a concentration of $70 \%$ to clean the inhalation chamber after each exposure and theDGB between exposure periods.

The chamber was ventilatedfor $5 \mathrm{~min}$, in the middle of the exposure experiment, through a hole located at the top of the glass inhalation chamber for the prevention of oxygen deprivation during the exposure time. Animals were dissected after the end of the exposure period. The normal paraffin method was followed in the preparation of the tissue slides for microscopic examination, where the samples were kept in formalin $10 \%$ and then transferred to ethanol $70 \%$ to study the histological changes for kidney and spleen. After fixation, both kidney and spleen were processed, wax blocks and slides were prepared andstained with hematoxyline and eosin(H\&E) [21].

\section{4- Statistical Analysis}

Statistical analysis was used to analyze factors variation in this study. The least significant 
difference-LSD test (ANOVA) was used to compare significant differences between means in this study [22].

\section{5-Results and Discussion}

\subsection{Weights of organs}

It seems clear upon examining the albino mice that increasingthe brake pad particles' period of exposure significantly affected the weights of kidney and spleen. The analysis shows highly significant differences $(\mathrm{P}<0.01)$ as compared with the control groups, as shown in the Table 1-2.

Table 1.2-Effects of difference groups of treatments with brake pad particles in kidney and spleen weights

\begin{tabular}{|c|c|c|}
\hline \multirow{2}{*}{ Groups } & \multicolumn{2}{|c|}{ Mean \pm SE } \\
\cline { 2 - 3 } & Spleen weight $(\mathbf{g})$ & Kidney weight $(\mathbf{g})$ \\
\hline Control & $0.220 \pm 0.03$ & $0.280 \pm 0.05$ \\
\hline 4 week & $0.198 \pm 0.03$ & $0.212 \pm 0.03$ \\
\hline 8 week & $0.322 \pm 0.01$ & $0.374 \pm 0.04$ \\
\hline 12 week & $0.560 \pm 0.14$ & $0.424 \pm 0.04$ \\
\hline LSD value & $0.267 * *$ & $0.122 * *$ \\
\hline
\end{tabular}

The statistical analysis in the present study revealed that increasing the period of exposure to brake pad particles resulted in increasedorgan weights for both kidneys and spleen, especially in group $\mathrm{C}$, when compared with the control group.

A previous study that tested differentconcentrations of metallic elementsfound in brake pads, examined withX-ray Fluorescence Spectroscopy (XRF), indicated high concentrations in the order of $\mathrm{Fe}>\mathrm{Cu}>\mathrm{Si}>\mathrm{S}>\mathrm{Sb}>\mathrm{Zn}>\mathrm{Mg}>\mathrm{Al}>\mathrm{Sn}>\mathrm{Cr}>\mathrm{Mo}$, whilethe concentrations of the other examined elements were within the range of the World Health Organization [23].

Iron is one of the most important mineral elements that can affect human health when increasing the accumulation within the body. A previous study revealed that iron, whengiven orally or with food for 18-20 weeks, causes an increase in the weight of the spleen, and thatincreasing the proportion of iron accumulation in the body of mice resulted in morphological changes in the spleen [24]. In another study,eight heavy metals ( $\mathrm{Zn}, \mathrm{Cu}, \mathrm{Mn}, \mathrm{Cr}, \mathrm{Ni}, \mathrm{Cd}, \mathrm{Pb}$, and $\mathrm{Hg}$ ) were assessed for their health effects. Their experiment was conducted on four groups of female rats, beside the control group. Each rat received orally a corresponding dose of $1000 \mathrm{mg} / \mathrm{kg}$ body weight. The results showed an increase in the weight of both kidney and spleen when compared with those of the control group[25].

\subsection{Histological examination}

In this study Figures-(1 and 2) show the effects on organs after and before exposure to brake pads particles.

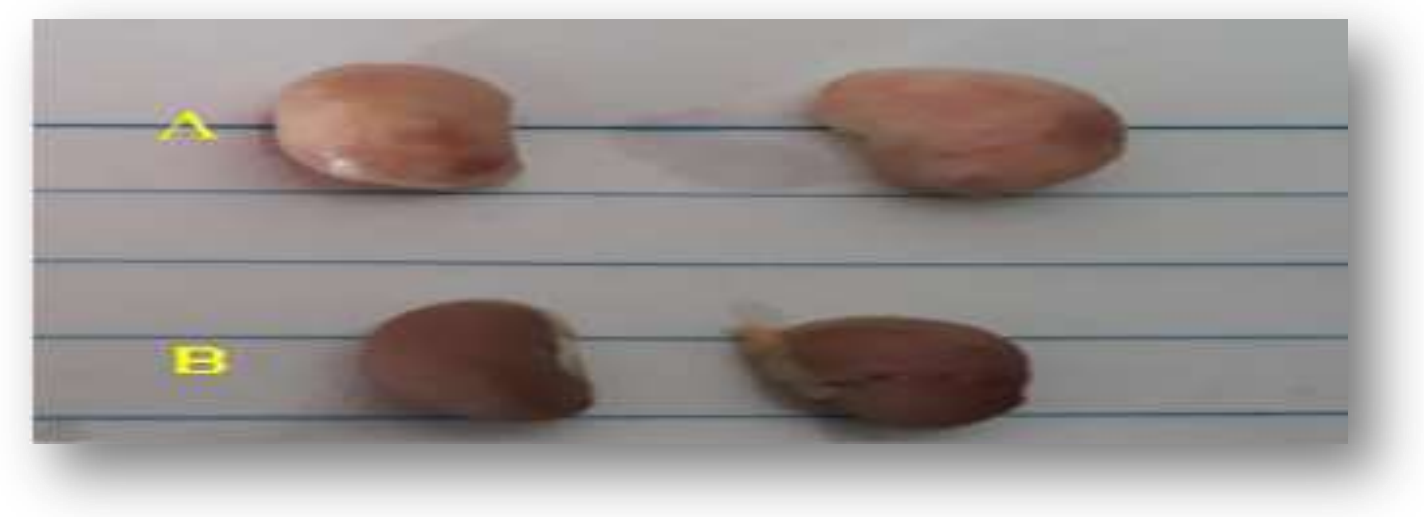

Figure 1-Gross samples of kidneyfrom group C(exposed for 12 weeks): (A) Exposure to brake pads particles and (B) Exposure to Fresh air, 1x magnification power (MP). 


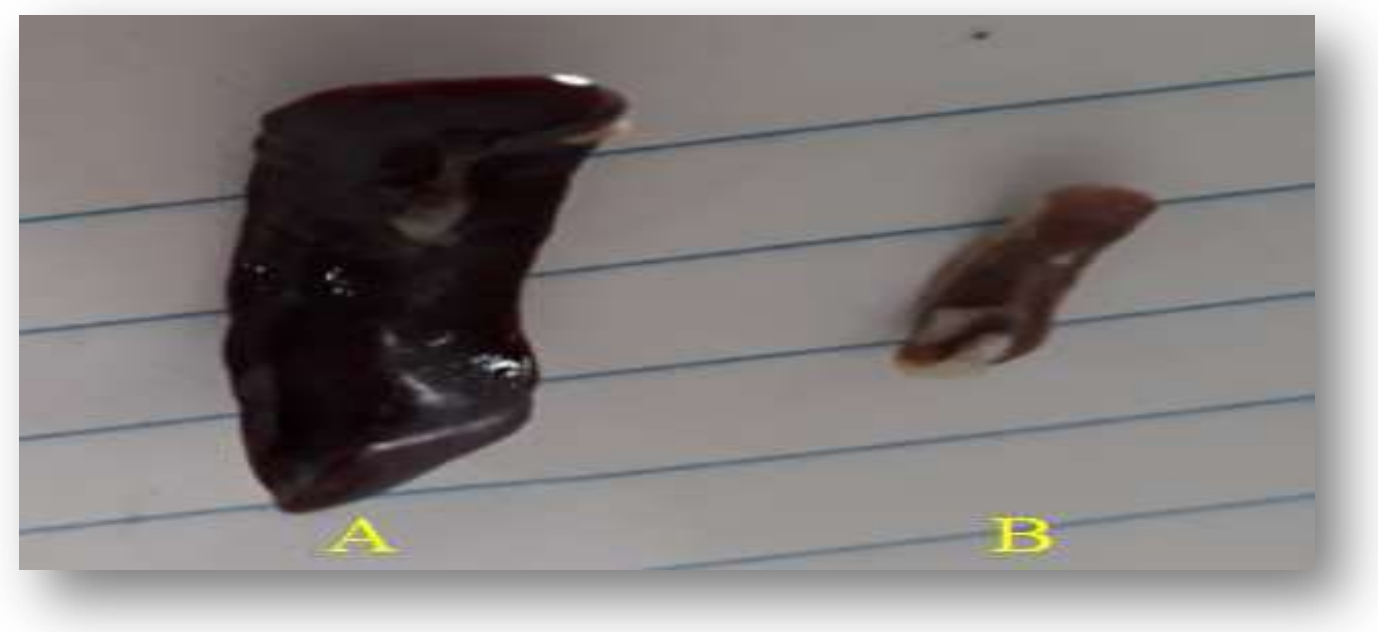

Figure 2-Gross samples of spleen from group C(exposed for 12 weeks) : (A) Exposure to brake pads particles and (B) Exposure to Fresh air, 1x magnification power (MP).

\section{Kidney}

Effects of brake pad particles on kidney histology were examined.The results of the exposure of the experimental group Aof micefor 4 weeks as compared with the control are shown in Figure-3.The sections of kidneys revealed subcapsular tubular vascular degeneration while the cortical region revealed mild focal hemorrhage (Figure-3 A2).
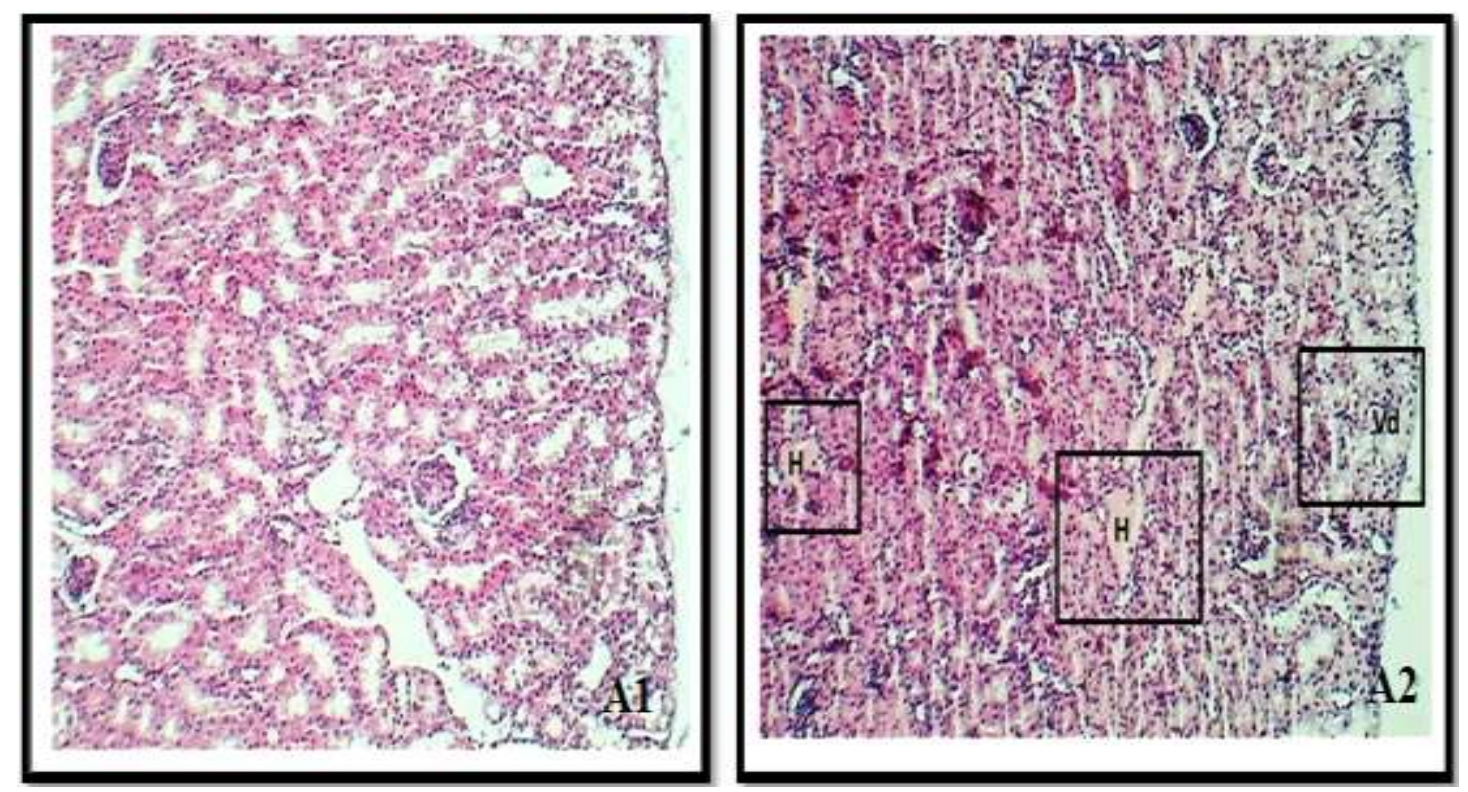

Figure 3-(A1) Section of a kidney (control). H\&E stain, 40x and (A2) Section of a kidney (group A) shows subcapsular vascular degeneration $(\mathrm{Vd})$ and focal hemorrhage $(\mathrm{H})$. H\&E stain, 40x

Histological examination of kidney for groups B (exposed for 8 weeks) and C(exposed for 12 weeks)showed similar results. Most sections of kidneys revealed moderate cortical vascular degeneration, cortico-medullary vascular congestion and focal interstitial nephritis characterized by thickening of interstitial tissue with infiltration of mononuclear lymphocytes (Figure-4 B1,B2). Other sections showed marked dilation of collecting ducts with tubular vascular degeneration, necrosis, glomerular degeneration and deterioration, and cast formation Figure-4 (B3).Similar changes were seen in the medulla Figure-4 (B4). 

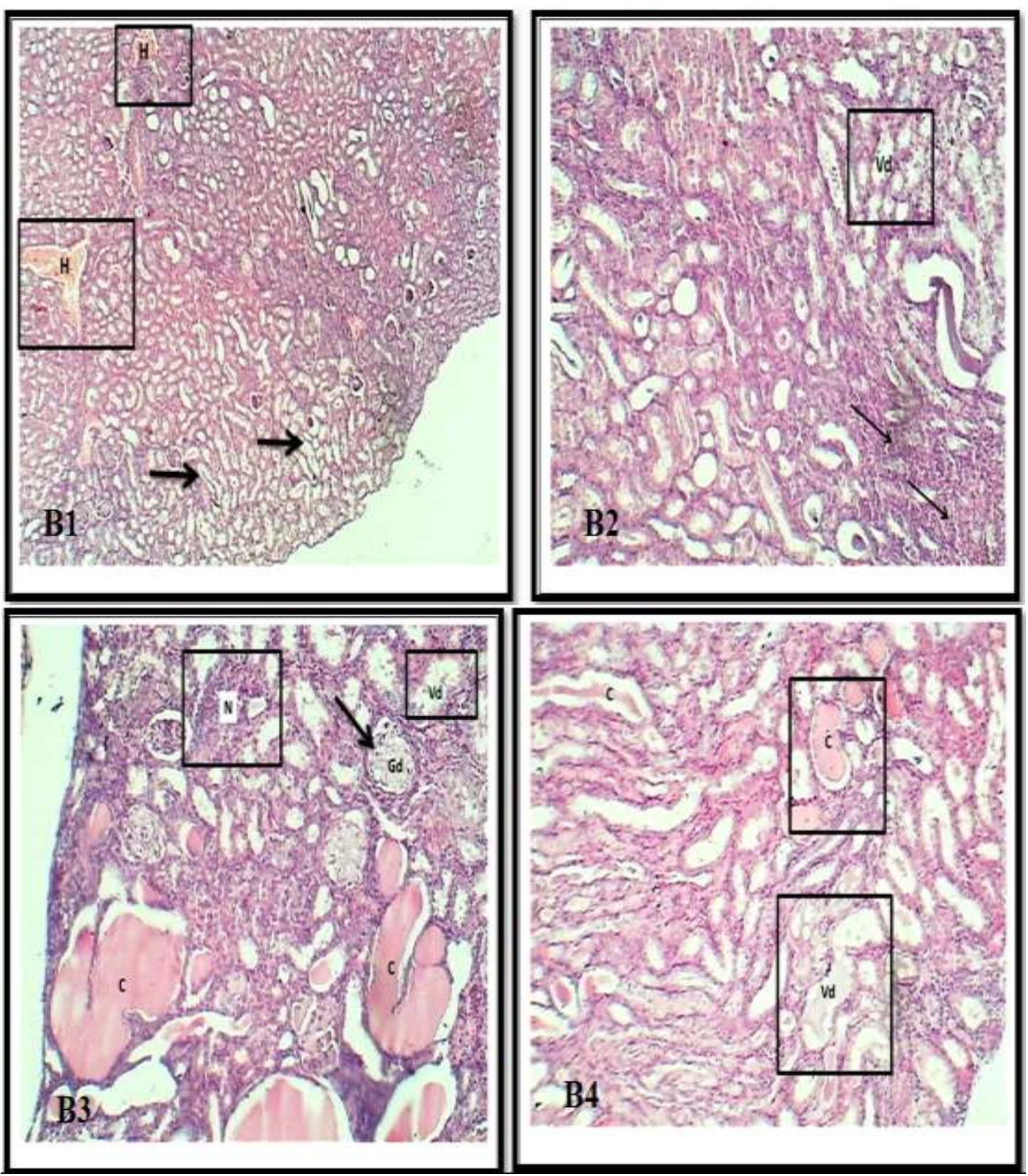

Figure 4 (B1)-Section of renal cortex (group B) shows: Hemorrhage $(\mathrm{H})$ and vascular degeneration (Black arrows) H\&E stain, 40x; (B2) Section of renal cortex (group A2) shows: tubular vacular degeneration $(\mathrm{Vd})$ and focal interstitial nephritis characterized by thickening of tissue (Black arrows). H\&E stain, 40x; (B3) Section of renal cortex (group B) shows: tubular vacular degeneration (Vd) with necrosis $(\mathrm{N})$, glomerular degeneration and deterioration $(\mathrm{Gd})$, and cast formation $(\mathrm{C})$. H\&E stain, 100x and (B4) Section of renal medulla (group B) shows: tubular vacular degeneration (Vd) and cast formation (C). H\&E stain 100x.

Spleen

Histological examination of spleen from group A, in comparison with the control, is demonstrated in Figure-5. The sections of spleen revealed only mild subcapsular vacular degenerationof lymphocytes Figure- 5 (A2,A3). 

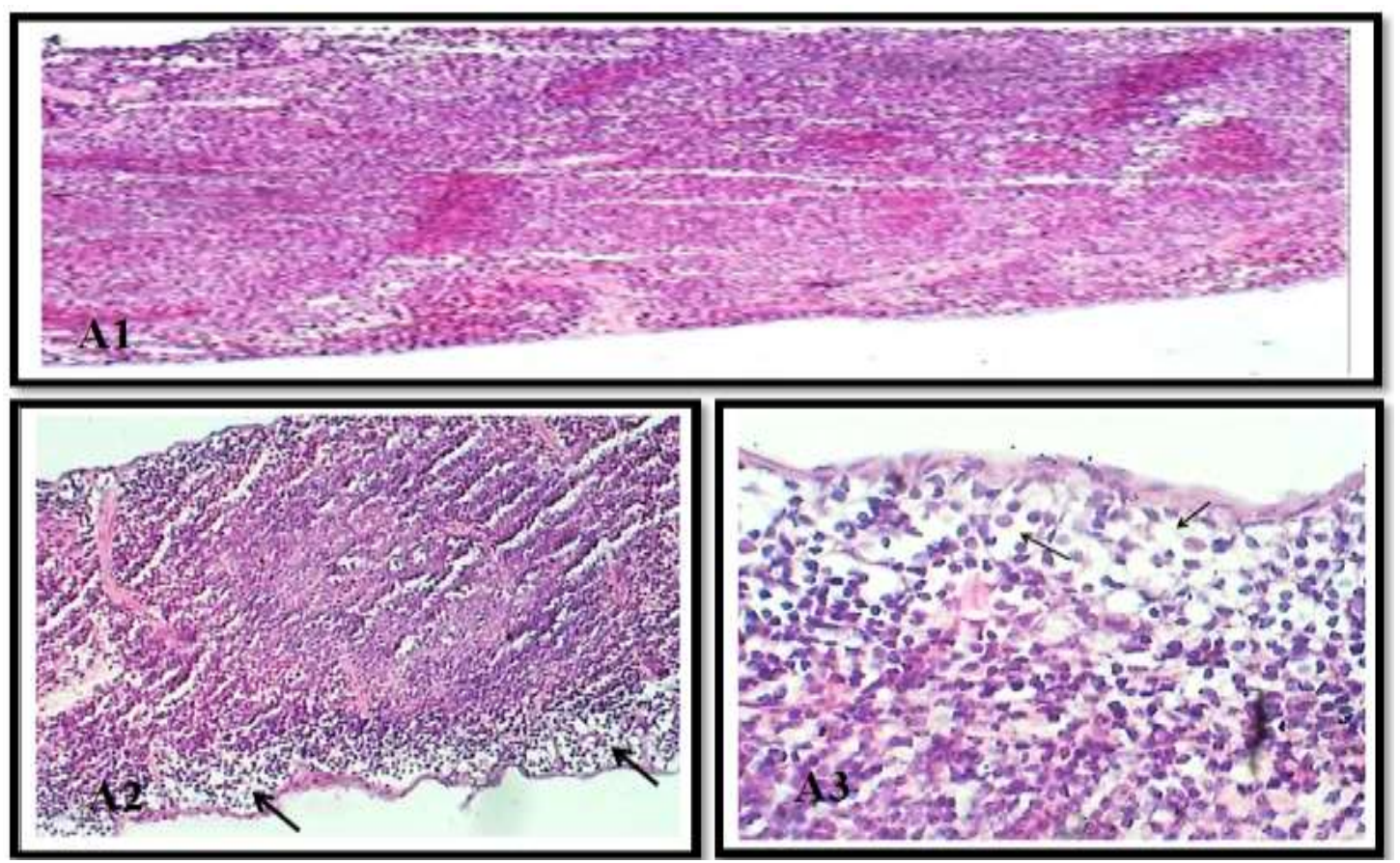

Figure 5 (A1)-Section of the spleen (control). H\&E stain, 40x; (A2) Section of spleen (group A).shows: subcapsular macular degeneration (Black arrows).H\&E stain. 40x and (A3) Magnified section of the spleen (group A).shows: subcapsular vascular degeneration of lymphocytes (Black arrows). H\&E stain. 40x.

However, histological examination of spleen sectionsfromgroup Brevealed moderated amyloid deposited with hemosiderosis, whilemild subcapsular vascular degeneration of lymphocytes was observed within the red pulp Figure-6 (B1,B2).
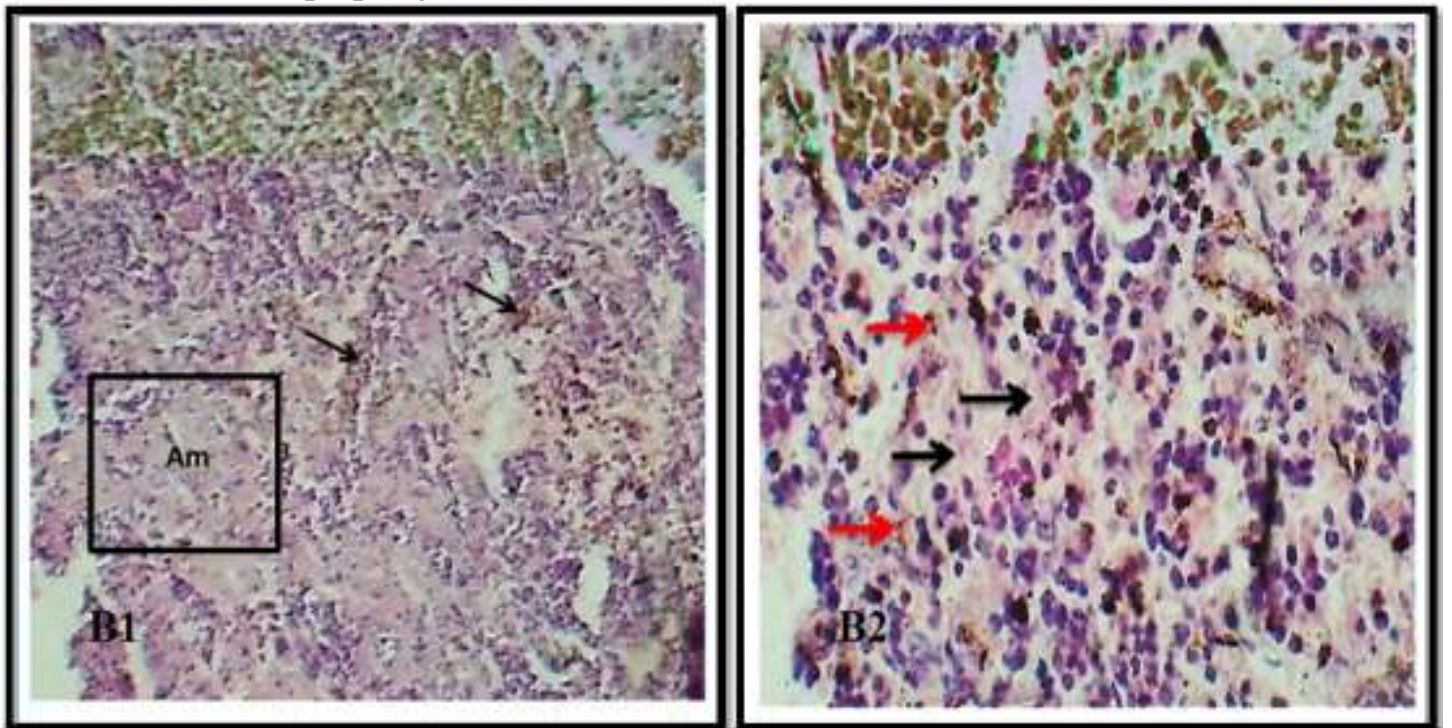

Figure 6 (B1)-Section of spleen (group B) shows: amyloid deposited (Am) and hemosiderosis (Black arrows). H\&E stain. 20x and (B2) Magnified section of the spleen (group B) shows: amyloid deposited (Black arrows) and hemosiderosis (red arrows). H\&E stain. 40x.

Finally,histological examination of the spleen sections from group $\mathrm{C}$ revealed severe splenomegaly with advanced secondary splenic amyloidosis within the red pulp, which characterized marked deposited acellular and amorphous pinkish homogenous material within the red pulp Figure-(7 C1, C2). 


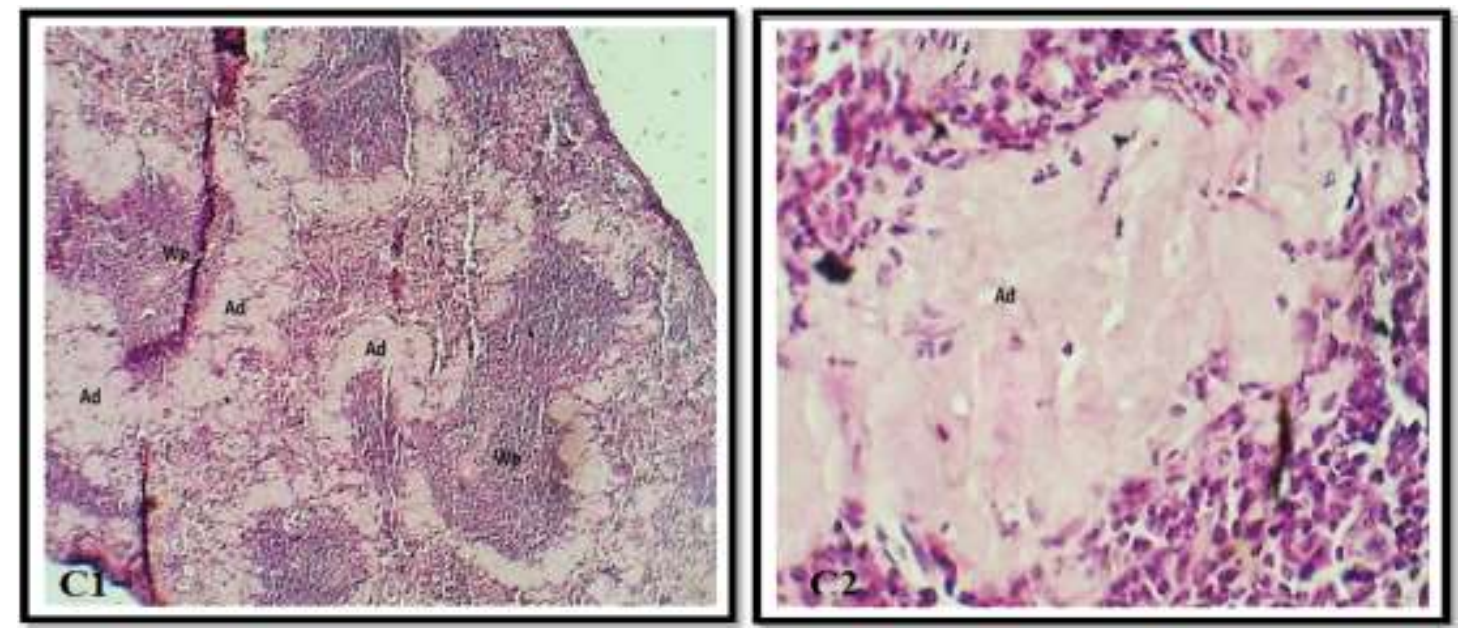

Figure 7 (C1)-Section of the spleen (group C) shows: advanced amyloidosis (Ad).H\&E stain. 40x and (C2) Magnified section of the spleen (group C) shows: deposit of amorphous homogenous material (amyloid) (Ad).H\&E stain 40x.

The results show higher adverse effectsof histological changesin group $\mathrm{C}$,which was exposed for 12 weeks tobrake pad particles, than the other groups which might contain different levels of minerals. This finding accords with the results of a previous study which mentioned that there are mechanisms that cause diseases whenmineral particles are inhaled for long period (chronic exposure). There are factors that can be taken into account when dealing with disease potential of a particular exposure , which include duration and frequency of exposures, tissue-specific dose over time, impacts onin vivo dose persistence,the mineral type, and surface characteristics. Reports indicated that mineral particles damage cellular molecules and contribute to necrosis, exudate formation, and inflammation. This may involve an unfortunate ability of mineral particles to chemically generate potentially damaging reactive oxygen species (ROX) [26].

Numerous studies reported that some of the heavy metals, such as cadmium, induced apoptosis related to oxidative stress in various cells including renal cells [27]. In a study conducted on mice, it was observed that $90 \%$ of the air particles taken in by inhalation are respired by the lungs. The particles reaching the alveolus are then transported by the blood to the circulation system. The lead excretion rate was shown to beextremely slow because the lead is ingested orally at a rate of about $0.300-0.500 \mathrm{mg} / \mathrm{day}$ and accumulates within the body [28]. In a previous study, it was found that the lead accumulates in the soft tissues of adults and children and could be distributed by blood circulation to kidneys, lungs, spleen, and muscle tissue. Kidneys excrete $75 \%$ of the daily lead intake without altering it [29].

In another study,the toxic effects were examined on animals fed intragastrically with $10 \mathrm{mg} / \mathrm{kg}$ body weight cadmium (Cd), $200 \mathrm{mg} / \mathrm{kg}$ body weight zinc, or $1.2 \mathrm{~g} / \mathrm{kg}$ body weight aluminum (daily for thirty days), which is a low dose on sensitive organs like kidney and liver on mice. Only cadmium decreased the animal's body weight. It was observed that zinc alone resulted in drastic effects on kidney tissues that were stronger than those caused bycadmium or aluminum, while cadmium and aluminum resulted in infiltration of the liver parenchyma with lymphocytes, microvesicular steatosis of the hepatocytes, fibrosis, appearance of many phagocytic cells, and vacuolation [30].

Another study indicated that heavy metals such as Nickel (Ni) and chrome $(\mathrm{Cr})$ caused toxicity and carcinogenicity on the liver and kidney of swiss male mice, whose weights ranged 20-30 g and ages 10-13 weeks. The animals were treated orally with different doses $(20,60$ and $100 \mathrm{mg} / \mathrm{kg}$ of chrome and 20, 40 and $60 \mathrm{mg} / \mathrm{kg}$ of Nickel). The histopathological changes in the liver and kidney of treated animals included degeneration, cellular swelling, nuclear pycnosis, congestion of blood vessels, necrosis, and many others defects [31]. Lead is considered to be one of the heavy metals in the environment where it is dangerous in case of higher levels than thenatural limit.Leads induces immunotoxicity and anemia. A previous studydemonstrated haematic and histopathological changes in the spleen of mice treated with medium doses of $\mathrm{Pb}(200 \mathrm{mM} / \mathrm{ppm})$ in drinking water for 45 days. Within the spleen, higher $\mathrm{Fe}(\mathrm{II})$ and $\mathrm{Fe}$ (III) deposits were found inside the macrophages, in addition to apoptosis, oxidative stress, and dysregulated autophagy in spleen compartments [32]. In a study 
conducted on rats to observe both immunosuppressive and pro-inflammatory effects in the spleen tissue, administration of $0.5 \mathrm{mg} / \mathrm{kg}$ on iron caused an increase of spleen cells and complexity of immunomodulatory effects of this metal [33]. Another study showed that the accumulation of elevated iron ratios within the body can affect the body's organs, influencing the liver, spleen and bone marrow cells. The histopathological studies showed acute and chronic inflammatory diseases, chronic liver diseases, and oxidative stress.Exposure to iron results in iron accumulation in parenchymal cells along with fibrosis.There were alsopositive correlations between liver, splenic, and bone marrow iron accumulation in patients with different diffuse liver diseases [34].

In conclusion, the present study provides an evidence concerning the toxic and adverse effects of brake pad particles in the kidneys and spleen of albino mice after inhalation. Therefore, break pad particlesare considered as an important non-exhaust air pollutant.

\section{6-References}

1. Boubel, R. W., Fox, D. L., Turner, D. B. and Stern, A. C. 1994. Fundamentals of air pollution.3rd edition. Academic Press. Elsevier, USA. pp.555.

2. Environmental Protection Agency (EPA) .2010. Air pollution. Health, environmental, and climate. http://www.epa.gov/airtrends/2010/report/airpollution.

3. Khitoliya, R.K 2004. Environmental Pollution. S. Chand and Company LTD, India. pp: 102-139.

4. Karanasiou, A., Amato, F., Moreno, T., Lumbreras, J., Borge, R., Linares, C., Boldo, E., Alastuey, A. and Querol, X. 2014. Road dust emission sources and assessment of street washing effect. Journal of Aerosol Air Quality and Researchers, 14(3): 734-743.

5. Wahlstrom, J. 2016. A factorial design to numerically study the effects of brake pad properties on friction and wear emissions. Advances in Tribology, 2016: 1-10.

6. Sanders, P. G., Xu, N., Dalka, T. M. and Maricq, M. M. 2003. Airborne brake wear debris: size distributions, composition, and a comparison of dynamometer and vehicle tests. Journal of Environmental science and technology, 37(18): 4060-4069.

7. Wahlstrom, J., Soderberg, A., Olander, L., Jansson, A. and Olofsson, U. 2010. A pin-on-disc simulation of airborne wear particles from disc brakes. Journal of Wear, 268(5-6): 763-769.

8. Gietl, J. K., Lawrence, R., Thorpe, A. J. and Harrison, R. M. 2010. Identification of brake wear particles and derivation of a quantitative tracer for brake dust at a major road. Journal of Atmospheric environment, 44(2): 141-146.

9. Amato, F., Pandolfi, M., Escrig, A., Querol, X., Alastuey, A., Pey, J., Perez, N. and Hopke, P.K. 2009. Quantifying road dust resuspension in urban environment by multilinear engine: a comparison with PMF2. Journal of Atmospheric Environment, 43(17): 2770-2780.

10. Karanasiou, A., Moreno, T., Amato, F., Lumbreras, J., Narros, A., Borge, R., Tobías, A., Boldo, E., Linares, C., Pey, J., Reche, C., Alastuey, A. and Querol, X. 2011. Road dust contribution to PM levels-evaluation of the effectiveness of street washing activities by means of positive matrix factorization. Journal of Atmospheric Environment, 45(13): 2193-2201.

11. Gehring, U., Beelen, R., Eeftens, M., Hoek, G., de Hoogh, K., de Jongste, J., Johan, C., Keuken, M., Koppelman, G., Meliefste, K., Oldenwening, M., Postma, D., vanRossem, L., Wang, M., Smit, H. and Brunekreef, B. 2015. Particulate matter composition and respiratory health: the PIAMA Birth Cohort Study. Journal of Epidemiology, 26 (3): 300-309.

12. Harrison, R. M., Jones, A. M., Gietl, J., Yin, J. and Green, D. C. 2012. Estimation of the contributions of brake dust, tire wear, and resuspension to non-exhaust traffic particles derived from atmospheric measurements. Journal of Environmental science and technology, 46(12): 65236529.

13. Lawrence, S., Sokhi, R., Ravindra, K., Mao, H., Prain, H. D. and Bull, I. D. 2013. Source apportionment of traffic emissions of particulate matter using tunnel measurements. Journal of Atmospheric Environment, 77: 548-557.

14. Valavanidis, A., Fiotakis, K. and Vlachogianni, T. 2008. Airborne particulate matter and human health: toxicological assessment and importance of size and composition of particles for oxidative damage and carcinogenic mechanisms. Journal of Environmental Science and Health, Part C, 26(4): 339-362. 
15. Borja - Aburto, V.H., Castillejos, M., Gold, D.R., Bierzwinski, S. and Loomis, D. 1998. Mortality and ambient fine particles in southwest Mexico City, 1993-1995. Journal of Environmental Health Perspectives, 106(12): 849-855.

16. Ghio, A. J., Silbajoris, R., Carson, J. L. and Samet, J. M. 2002. Biologic effects of oil fly ash. Journal of Environmental health perspectives, 110 (Suppl 1): 89-94.

17. Ghio, A. J. 2009. Disruption of iron homeostasis and lung disease. Journal of Biochimica et Biophysica Acta (BBA)-General Subjects, 1790(7): 731-739.

18. Gasser, M., Riediker, M., Mueller, L., Perrenoud, A., Blank, F., Gehr, P. and Rothen-Rutishauser, B. 2009. Toxic effects of brake wear particles on epithelial lung cells in vitro. Journal of Particle and fiber toxicology, $\mathbf{6}(1)$ : 30.

19. Iijima, A., Sato, K., Yano, K., Kato, M., Kozawa, K. and Furuta, N. 2008. Emission factor for antimony in brake abrasion dust as one of the major atmospheric antimony sources. Journal of Environmental Science and Technology, 42(8): 2937-2942.

20. Kukutschova, J., Moravec, P., Tomasek, V., Matejka, V., Smolk, J., Schwarz, J., Seidlerova, J., Safarova, K. and Filip, P. 2011. On airborne nano/microsized wear particles released from lowmetallic automotive brakes. Journal of Environmental Pollution, 15(4): 998-1006.

21. Bancroft, J.D. and Gamble, M. 2008. Theory of practice and histological techniques. 6th Churchill living stone. Elsevier Health Sciences, 725 P.

22. SAS. 2012. Statistical Analysis System, User's Guide. Statistical. Version 9.1th ed. SAS. Inst. Inc. Cary. N.C. USA.

23. Ghaidan, H. Q. and Al-Easawi, N. A. F. 2019. Evaluation of the Physical and Chemical Properties of Vehicles Brake Pad Particles. Iraqi Journal of Science, 60(3): 438-447.

24. Yamano, N., Ikeda, Y., Sakama, M., Izawa-Ishizawa, Y., Kihira, Y., Ishizawa, K., Miyamoto, L., Tomita, S., Tsuchiya, K. and Tamaki, T. 2015. A long-term high-fat diet changes iron distribution in the body, increasing iron accumulation specifically in the mouse spleen. Journal of Nutritional science and vitaminology, 61(1): 20-27.

25. Kenston, S. S. F., Su, H., Li, Z., Kong, L., Wang, Y., Song, X., Gu, Y., Barber, T., Aldinger, J. and Hua, Q. 2018.The systemic toxicity of heavy metal mixtures in rats. Journal of Toxicology Research, 7(3): 396-407.

26. Aust, A. E., Cook, P. M. and Dodson, R. F. 2011. Morphological and chemical mechanisms of elongated mineral particle toxicities. Journal of Toxicology and Environmental Health, Part B, 14(1-4): 40-75.

27. Nemmiche, S., Chabane-Sari, D., Kadri, M. and Guiraud, P. 2012. Cadmium-induced apoptosis in the BJAB human B cell line:involvement of PKC/ERK1/2/JNK signaling pathways in HO-1 expression. Journal of Toxicology, 300(3): 103-111.

28. Ellenhorn, M. J. and Barceleoux, G. D. 1990. Medical Toxicology: Diagnosis and Treatment of Human Poisoning. New York, NY, USA: Williams and Wilkins, pp. 1030-1041.

29. Klaassen, C. D., Amdur, M. O. and Doull, J. 1996. Casarett and Doull's Toxicology: The Basic Science of Poisons. Klaassen CD, editor. New York, NY, USA: McGraw-Hill, pp. 703-709.

30. Ibraheem, A. S., Seleem, A. A., El-Sayed, M. F. and Hamad, B. H. 2016. Single or combined cadmium and aluminum intoxication of mice liver and kidney with possible effect of zinc. Journal of Basic and Applied Zoology, 77: 91-101.

31. Al-fatlawi, A. C. 2017. Histopathological changes of heavy metals Nickel Chloride (II) and Potassium dichromate (VI) on the Liver and Kidney of Swiss Male Mice. Journal of karbala pharmaceutical sciences, (13): 221-230.

32. Corsetti, G., Romano, C., Stacchiotti, A., Pasini, E. and Dioguardi, F. S. 2017. Endoplasmic reticulum stress and apoptosis triggered by sub-chronic lead exposure in mice spleen: a histopathological study. Journal of Biological trace element research, 178(1): 86-97.

33. Demenesku, J., Mirkov, I., Ninkov, M., Aleksandrov, A. P., Zolotarevski, L., Kataranovski, D. and Kataranovski, M. 2014. Acute cadmium administration to rats exerts both immunosuppressive and proinflammatory effects in spleen. Journal of Toxicology, 326: 96-108.

34. Franca, M., Marti-Bonmati, L., Porto, G., Silva, S., Guimaraes, S., Alberich-Bayarri, A., Vizcaino, J.R. and Miranda, H. P. 2018. Tissue iron quantification in chronic liver diseases using MRI shows a relationship between iron accumulation in liver, spleen, and bone marrow. Journal of Clinical radiology, $\mathbf{7 3}(2)$ : 215 -e1. 